\title{
Neurological associations of chronic heart block
}

\author{
C. D. LA M B E R T A N D A. J. F A I R F A X \\ From the Departments of Neurology and Cardiology, St. George's Hospital, London
}

SYNOPSIS A large group of patients with chronic heart block was studied for evidence of neurological disorder. Six out of 892 patients were found who had neuromuscular disease related to the conduction disturbance. In four patients, cardiac involvement appeared selectively to affect the conducting tissues. Three of these patients had a scapuloperoneal syndrome, the fourth, the oculocraniosomatic syndrome. In the remaining two patients, one with limb girdle dystrophy and the other with dystrophia myotonica, cardiomyopathy was present in addition to the conduction disturbance.

This paper reports the first comprehensive study of the frequency and nature of neurological disorders occurring in association with complete heart block. The most common pathological cause of chronic heart block is idiopathic bundle branch fibrosis (Davies, 1971) thought by Lenègre, who described it, to be a selective myopathy of the cardiac conducting tissues (Lenègre, 1964). His original series of 66 cases contained two patients with 'muscular dystrophy of a type difficult to classify.' The aim of this paper was, therefore, to classify the types of neuromuscular disorder which occur in patients with complete heart block and to find how frequently this association accounts for the development of atrioventricular dissociation in the population at large.

\section{METHODS}

The case records of 892 patients with chronic complete heart block from the cardiological departments of St. George's Hospital and the National Heart Hospital were studied for evidence of neurological abnormality. To confirm that the documentation of the patients was adequate, a random sample of $20 \%$ of the total group was interviewed and examined personally. Patients

Address for correspondence: Dr C. D. Lambert, Atkinson Morley Hospital, Wimbledon, London SW20 0NE.

(Accepted 22 January 1976.) with incomplete heart block or transient heart block secondary to myocardial infarction were not included.

Those cases with evidence of neuromuscular disease were examined in detail, a family history taken, serum creatine phosphokinase levels measured and, when possible, electromyography performed. Muscle biopsy specimens, obtained under local anaesthetic, were examined using conventional morphological and histochemical techniques (Dubowitz and Brooke, 1973).

\section{RESULTS}

The 892 patients (501 male, 391 female) who were studied were aged between 2 and 97 years, with a mean of 70 years. Among 675 patients with idiopathic heart block there were six with neuromuscular abnormalities considered to be related aetiologically to the development of their disturbance of cardiac conduction. Three patients had a scapuloperoneal syndrome and the others had respectively limb girdle dystrophy, dystrophia myotonica, and the oculocraniosomatic syndrome (Tables 1 and 2).

\section{CASE 1}

A.H., a 54 year old male decorator, noticed weakness in his left foot at the age of 39 years; this was followed by weakness of both shoulders. Ten years later difficulty in rising from a chair became evident. Cardiac symptoms from complete heart 
TABLE 1

NEUROLOGICAL DATA: SIX PATIENTS WITH ATRIOVENTRICULAR HEART BLOCK AND NEUROMUSCULAR DISEASE

\begin{tabular}{|c|c|c|c|c|c|c|c|c|c|}
\hline \multirow{2}{*}{$\begin{array}{l}\text { Case } \\
\text { no. }\end{array}$} & \multirow[t]{2}{*}{ Sex } & \multirow{2}{*}{$\begin{array}{l}\text { Family } \\
\text { history }\end{array}$} & \multicolumn{3}{|c|}{ Age (yr) } & \multirow{2}{*}{$\begin{array}{c}\text { Clinical } \\
\text { classification }\end{array}$} & \multirow{2}{*}{$\begin{array}{l}\text { Serum } \\
\text { CPK } \\
\text { Iu } / l\end{array}$} & \multirow[t]{2}{*}{$E M G$} & \multirow{2}{*}{$\begin{array}{c}\text { Muscle } \\
\text { biopsy }\end{array}$} \\
\hline & & & $(a)$ & (b) & $\overline{(c)}$ & & & & \\
\hline 1 & $\mathbf{M}$ & - & 39 & 47 & 54 & $\begin{array}{l}\text { Scapuloperoneal } \\
\text { dystrophy }\end{array}$ & 17 & Myopathic & Myopathy \\
\hline 2 & $\mathbf{M}$ & - & $20 s$ & 69 & 80 & $\begin{array}{l}\text { Scapuloperoneal } \\
\text { syndrome }\end{array}$ & 145 & - & - \\
\hline 3 & $\mathbf{M}$ & + & 35 & 62 & 69 & $\begin{array}{l}\text { Scapuloperoneal } \\
\text { dystrophy }\end{array}$ & 69 & Myopathic & Myopathy \\
\hline 4 & $\mathbf{F}$ & - & $\begin{array}{l}\text { Child- } \\
\text { hood }\end{array}$ & 33 & 39 & $\begin{array}{l}\text { Limb girdle } \\
\text { dystrophy }\end{array}$ & 176 & Myopathic & Myopathy \\
\hline 5 & $\mathbf{M}$ & - & 15 & - & 22 & $\begin{array}{l}\text { Oculocraniosomatic } \\
\text { syndrome }\end{array}$ & 57 & Myopathic & $\begin{array}{l}\text { Mitochondrial } \\
\text { myopathy }\end{array}$ \\
\hline 6 & $\mathbf{F}$ & + & $20 \mathrm{~s}$ & 59 & 63 & $\begin{array}{l}\text { Dystrophia } \\
\text { myotonica }\end{array}$ & - & Myotonia & - \\
\hline
\end{tabular}

a: age onset neurological illness.

CPK = Creatine phosphokinase.

b: age onset cardiac symptoms.

EMG = Electromyogram.

c: age at study.

TABLE 2

CARDIOLOGICAL DATA: SIX PATIENTS WITH ATRIOVENTRICULAR HEART BLOCK AND NEUROMUSCULAR DISEASE

\begin{tabular}{|c|c|c|c|c|c|c|}
\hline $\begin{array}{l}\text { Case } \\
\text { no. }\end{array}$ & $\operatorname{Sex}$ & $\begin{array}{l}\text { Age } \\
(y r)\end{array}$ & $\begin{array}{c}\text { Cardiac } \\
\text { symptoms }\end{array}$ & $\begin{array}{c}\text { Cardiac } \\
\text { enlargement } \\
(X-\text { ray })\end{array}$ & $\begin{array}{c}\text { Electrocardiogram } \\
\text { QRS width } \\
(s)\end{array}$ & Comments \\
\hline 1 & $\mathbf{M}$ & 54 & $\begin{array}{l}\text { Dizzy spells } \\
\text { Exertional dyspnoea } \\
\text { Palpitations }\end{array}$ & Nil & 0.08 & Normal QRS \\
\hline 2 & $\mathbf{M}$ & 80 & Syncope & Slight & 0.14 & R. BBB pattern \\
\hline 3 & $\mathbf{M}$ & 69 & Syncope & Nil & 0.16 & L. BBB pattern \\
\hline 4 & $\mathbf{F}$ & 39 & $\begin{array}{l}\text { Dizzy spells } \\
\text { Palpitations } \\
\text { Heart failure }\end{array}$ & Moderate & 0.08 & $\begin{array}{l}\text { Sinoatrial and a-v block } \\
\text { with paroxysmal } \\
\text { tachycardia }\end{array}$ \\
\hline 5 & $\mathbf{M}$ & 22 & Asymptomatic & Nil & 0.14 & $\begin{array}{l}\text { R. BBB and } L \text { axis } \\
\text { deviation }\end{array}$ \\
\hline 6 & $\mathbf{F}$ & 63 & Syncope & Slight & 0.16 & R. BBB pattern \\
\hline
\end{tabular}

BBB: bundle branch block.

block developed eight years after the onset of muscle disease. Although he had some exertional dyspnoea, there was no definite clinical or radiological evidence of heart failure and cardiomyopathy. The family history was negative.

Neurological examination showed bilateral wasting and weakness of the shoulder girdle musculature with winging of the scapulae. The triceps, biceps, and brachioradialis muscles were also weak. In the legs, wasting and weakness was distal and confined to the left side. All movements of the left foot were weak and foot drop was present but there was preservation of muscle bulk and power in the left extensor digitorum brevis muscle. There was additionally mild weakness of the musculature of the face, neck, and pelvic girdle. Reflexes and sensation were preserved, apart from loss of the left ankle jerk. Red-green colour blindness was found on testing.

\section{CASE 2}

M.S., born in 1894, noticed weakness of the right shoulder while on active service during the first world war. The left shoulder was affected 10 years later; he then observed thinning of the lower part of the left leg and developed foot drop for which a toe-spring was provided in 1940 . He worked as a farmer until right foot drop developed in 1967 and a second toe-spring was required. Syncopal attacks began in 1963. Complete heart block was present without evidence of myocardial involvement. The Stokes-Adams attacks were initially controlled by ephedrine but a pacemaker was required in 1974. $\mathrm{He}$ is now free of blackouts and leads an independent life.

There was no relevant family history. His only son showed no clinical or electrocardiographic abnormality. 
EXAMINATION There was gross muscle wasting and weakness of the shoulder girdle musculature (Figure (a)) and of the legs below the knee (Figure (b)) with bilateral foot drop. Power and bulk in the right extensor digitorum brevis was preserved but this muscle was atrophic on the left. Slight pelvic girdle and facial weakness were also present. There was no sensory loss and the reflexes, except for the ankle jerks, were preserved.

\section{CASE 3}

A.M., a man, showed winging of the scapula at a routine medical examination at the age of 35 years; symptomatic weakness developed five years later. The slow progression of the disorder has allowed full activity up to the age of 70 years except for some disability playing golf. Cardiac involvement became apparent at the age of 64 years with blackouts due to complete heart block.

A sister and one daughter were affected by dystrophy of scapuloperoneal distribution but also had facial weakness. At present neither shows conduction abnormalities on electrocardiography.

On examination there was weakness confined to the shoulder girdle and to the dorsiflexors and evertors of the feet. Sensation was normal and the tendon reflexes were preserved.

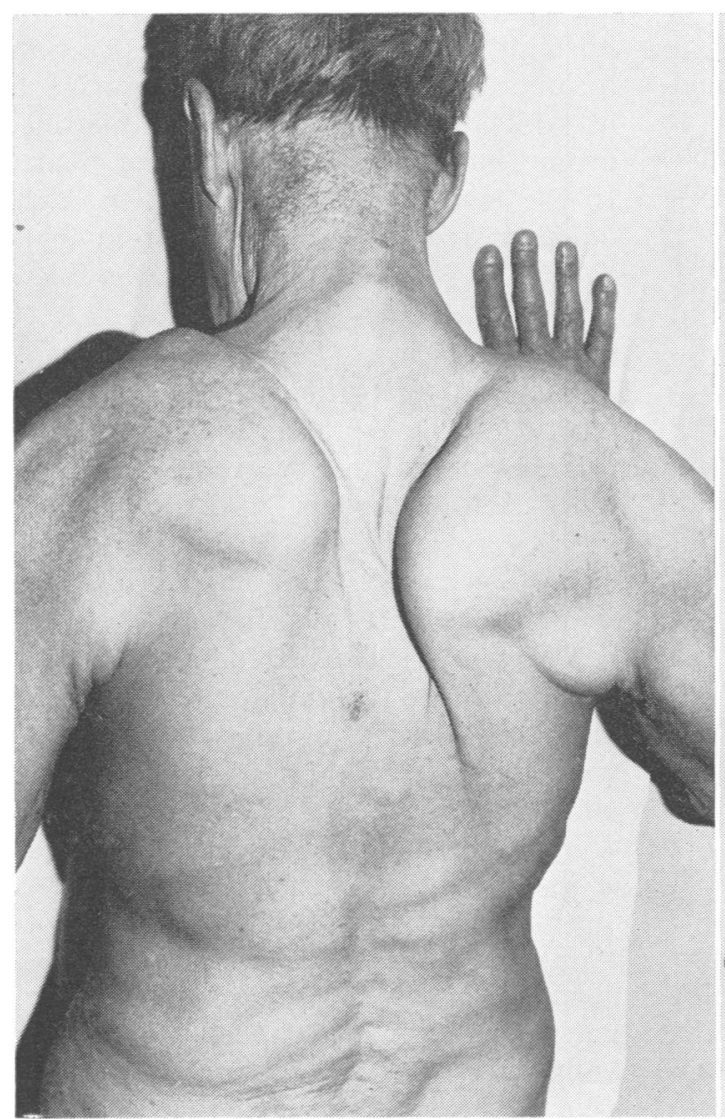

(a)

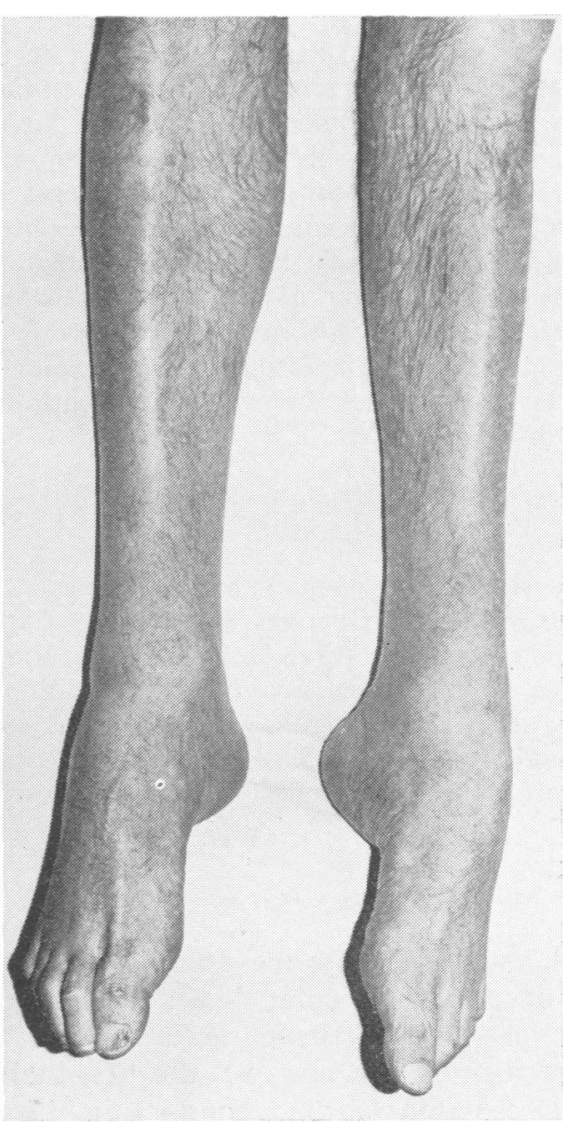

(b)

FIGURE Case 2. Scapuloperoneal syndrome: (a) wasting of shoulder girdle muscles with winging of the scapulae; (b) Selective involvement of the distal leg musculature with bilateral foot drop. 


\section{CASE 4}

M.C., a woman aged 39 years, presented in the first decade of life with a slowly progressive limb girdle dystrophy and had remained independent up to the time of examination. Cardiac symptoms developed at age 33 years with palpitations, dizzy spells, and heart failure. There was evidence of a cardiomyopathy with disease of the sinus node and of the peripheral conducting tissues resulting in complete atrioventricular dissociation and sinoatrial disorder.

\section{CASE 5}

J.C., a man, presented at the age of 15 years with short stature and was found later to have ptosis, external ophthalmoplegia, proximal limb weakness, ataxia, and retinitis pigmentosa. The cerebrospinal fluid protein was raised $(1.2 \mathrm{~g} / 1)$. A muscle biopsy showed many 'red-ragged' fibres to be present, thus confirming the diagnosis of oculocraniosomatic syndrome. Although he had no cardiac symptoms, serial electrocardiographs showed evidence of progressive peripheral conduction defect with evolution from left anterior hemiblock to bifascicular block and transient complete heart block over a period of seven years. There was no evidence of myocardial involvement. It is of interest that his father has unexplained bifascicular heart block but no other features of the syndrome.

\section{CASE 6}

L.E., a 64 year old woman, had the typical clinical features of dystrophia myotonica. Cardiac symptoms occurred three decades after the appearance of neurological symptoms. In addition to Stokes-Adams attacks from complete heart block, exertional dyspnoea and cardiomegaly suggested that there was also an underlying cardiomyopathy.

\section{DISCUSSION}

Neuromuscular disease was found to be a rare cause of atrioventricular heart block, being present in $0.7 \%$ of the patients studied. The patients formed two groups: the first had apparently isolated cardiac conduction disturbances, whereas the second group had a diffuse cardiomyopathy, with associated damage to the conducting tissue. The first group contained the three patients with a scapuloper- oneal syndrome and the patient with the oculocraniosomatic syndrome.

The three patients affected by the scapuloperoneal syndrome showed similar clinical features: all were men who had developed slowly progressive weakness in adult life but remained active up to 60 years after the onset of symptoms. In the two cases submitted to biopsy, a myopathic process was demonstrated. Two cases were sporadic, in the third a positive family history was obtained. Cardiac involvement became clinically apparent between eight and 50 years after the onset of skeletal muscle symptoms.

Cardiac involvement in the scapuloperoneal syndrome has been described only in recent years: in a current series (Thomas et al., 1975) the significance of the electrocardiographic abnormalities that were found was considered to be uncertain. Three reports describe families in which males with a scapuloperoneal syndrome have developed complete heart block. In the largest study, an X-linked scapuloperoneal dystrophy became apparent in the first decade of life. Sudden death was common in middle age and was attributed to cardiaco arrest, since heart block was demonstrated in five patients (Rotthauwe et al., 1972). In a second family with an X-linked scapuloperoneal dystrophy two brothers developed heart block before the age of 20 years (Mawatari and Katayama, 1973). In the third family described, in which two middle-aged brothers were affected, mixed myopathic and neurogenic changes were found (Takahashi et al., 1974). Diffuse conduction disturbances have also been described recently in two families with an X-linked humeroperoneal neuromuscular disease (Waters et al., 1975).

In the oculocraniosomatic syndrome (Olson et al., 1972), alternatively known as the 'opththalmoplegia plus' syndrome (Drachman, 1968), cardiac rhythm disturbances are an important cause of morbidity and mortality (Karpati et al., 1973; Schneck et al., 1973). In known cases, serial electrocardiograms enable asymptomatic progressive intraventricular conduction disturbances to be recognised before complete heart block develops (Kastor, 1975). Treatment with a cardiac pacemaker is a simple and effective method of preventing syn- 
cope and sudden death. Present evidence suggests that myocardial function is preserved in the oculocraniosomatic syndrome. There are as yet no detailed reports of the cardiac conducting tissues in this disorder but mitochondrial abnormalities have been found in skeletal muscle (Olson et al., 1972), cerebellum (Schneck et al., 1973), and eccrine sweat glands (Karpati et al., 1973) and it is tempting to speculate that similar changes will be found in the heart.

Cardiomyopathy produces a variety of cardiac conduction disturbances, including atrioventricular block. In a review of the literature, Flowers and Horan (1973) found complete heart block in $0.7 \%$ of patients with sporadic cardiomyopathy and in $7.0 \%$ of a group with familial cardiomyopathy. Postmortem studies of 177 patients with chronic heart block at St. George's Hospital showed a cardiomyopathy in 25 cases; only two of these had neuromuscular disease present-namely, dystrophia myotonica and Friedreich's ataxia (Davies, M. J., 1975, personal communication). Although cardiomyopathy has been described in one family with a scapuloperoneal syndrome (Thomas et al., 1972) our three cases had clinical evidence of damage localised to the conducting tissues.

The most common pathological change in the heart in chronic atrioventricular block is idiopathic bundle branch fibrosis, thought to represent the end stage of a number of possible disease processes in which the conducting tissues are damaged selectively (Davies, 1971). The clinical evidence presented in our study suggests that scapuloperoneal dystrophy and the oculocraniosomatic syndrome should be included as possible aetiological factors.

The authors wish to thank Dr Aubrey Leatham. Mr H. Siddons, Dr R. Emanuel, and Dr J. A. Morgan-Hughes for permission to study cases under their care and for helpful advice, and Miss Joan Hocker for secretarial assistance. A. J. F. was supported by a grant generously provided by the St. George's Hospital Research Fund.

\section{REFERENCES}

Davies, M. J. (1971). Pathology of the Conducting Tissue of the Heart. Butterworths: London.
Drachman, D. A. (1968). Ophthalmoplegia plus. The neuro degenerative disorders associated with progressive external ophthalmoplegia. Archives of Neurology, 18, 654-674.

Dubowitz, V., and Brooke, M. H. (1973). Muscle Biopsy: a Modern Approach. Saunders: London.

Flowers., N. C., and Horan, L. G. (1973). Electrocardiographic and vectorcardiographic features of myocardial diseases. In Myocardial Diseases, pp. 181211. Edited by N. O. Fowler. Grune and Stratton: New York.

Karpati, G., Carpenter, S., Larbrisseau, A., and Lafontaine, R. (1973). The Kearns-Shy syndrome. A multisystem disease with mitochondrial abnormality demonstrated in skeletal muscle and skin. Journal of the Neurological Sciences, 19, 133-151.

Kastor, J. A. (1975). Current concepts: atrio-ventricular block (part 1). New England Journal of Medicine, 292, 462-465.

Lenègre, J. (1964). Aetiology and pathology of bilateral bundle branch block in relation to complete heart block. Progress in Cardiovascular Diseases, 6, 409-444.

Mawatari, S., and Katayama, K. (1973). Scapuloperoneal muscular atrophy with cardiopathy. Archives of Neurology, 28, 55-59.

Olson, W., Engel, W. K., Walsh, G. O., and Einaugler, R. (1972). Oculocraniosomatic neuromuscular disease with 'red-ragged' fibers. Archives of Neuro$\log y, 26,193-211$.

Rotthauwe, H. W., Mortier, W., and Beyer, H. (1972). Neuer typ einer recessiv X-chromosomal vererbten Muskeldystrophie: Scapulo-humero-distale Muskeldystrophie mit frühzeitigen Kontrakturen und Herzrhythmusstörungen. Humangenetik, 16, 181-200.

Schneck, L., Adachi, M., Briet, P., Wolintz, A., and Volk, B. W. (1973). Ophthalmoplegia plus with morphological and histochemical studies of cerebellar and muscle tissue. Journal of the Neurological Sciences, 19, 37-44.

Takahashi, K., Nakamura, H., and Nakashima, R. (1974). Scapuloperoneal dystrophy associated with neurogenic changes. Journal of the Neurological Sciences, 23, 575-583.

Thomas, P. K., Calne, D. B., and Elliott, C. F. (1972). $\mathrm{X}$-linked scapuloperoneal syndrome. Journal of Neurology, Neurosurgery, and Psychiatry, 35, 208-215.

Thomas, P. K., Schott, G. D., and Morgan-Hughes, J. A. (1975). Adult onset scapuloperoneal myopathy. Journal of Neurology, Neurosurgery, and Psychiatry, 38, 1008-1015.

Waters, D. D., Nutter, D. O., Hopkins, L. C., and Dorney, E. R. (1975). Cardiac features of an unusual X-linked humeroperoneal neuromuscular disease. New England Journal of Medicine, 293, 1017-1022. 